\title{
A mouse intracerebral infection with Neisseria gonorrhoeae
}

\author{
B. B. DIENA, A. RYAN, F. E. ASHTON, AND R. WALlACE \\ Bacterial Immunology Division, Laboratory Centre for Disease Control, Health and Welfare, Canada \\ AND \\ M. B. PERRY AND V. DAOUST \\ Biological Sciences Division, National Research Council, Canada
}

Kellogg, Peacock, Deacon, Brown, and Pirkle (1963) described four colony types of Neisseria gonorrhoeae. Subsequently, these authors reported that colony types 1 and 2 ( $\mathrm{T} 1, \mathrm{~T} 2$ ) were virulent for human volunteers while $\mathrm{T} 3$ and $\mathrm{T} 4$ were avirulent. However, studies on the immunology and pathogenesis of $N$. gonorrhoeae colony types have been limited by the lack of an animal model susceptible to $N$. gonorrhoeae infection. Brown, Lucas, and Kuhn (1972) have recently described the experimental infection of the chimpanzee with both fresh gonorrhoeal pus and with T1 colonial type of $N$. gonorrhoeae: the cost and scarcity of this animal, however, severely limit the use of this model. Arko (1972) and Flynn and Waitkins (1973) have reported the in vivo cultivation of gonococci in surgically-implanted chambers in laboratory rodents. Buchanan and Gotschlich (1973) and Bumgarner and Finkelstein (1973) have used the chick embryo for the study of the virulence of gonococci; the value of these techniques for immunological studies remains to be defined.

This report describes the intracerebral challenge of the C57 mouse with $N$. gonorrhoeae and its application in the assay of experimental gonococcal vaccines.

\section{Material and methods}

\section{(A) N. gonorrhoeae strains}

Those used included No. 188, received from the Ontario Public Health Laboratory, Toronto, Ontario; No. G9, obtained from Dr. H. Schneider, Walter Reed Army Institute of Research, Washington, D.C.; Nos. IN15, IN17, IN21, and IN31 isolated from asymptomatic carriers during a gonococcal vaccine trial in Inuvik, North West Territories, Canada (Greenberg, Diena, Ashton, Wallace, Kenny, Znamirowski, Ferrari, and Atkinson, 1974); Nos. 1630, 1631, 1639, 1646, and 1676 received

Received for publication July 3, 1974

*The financial support of the World Health Organization is gratefully acknowledged

†Crossbreed of strains C57 B/10 V (Jackson Laboratories, Bar Harbor, Maine) and C57 B/6 (P) (Flow Laboratories, Dublin, Virginia), randomly bred at the Breeding Colony of the Health Protection Branch, Health and Welfare, Ottawa, Canada. from the Bacteriological Laboratories of the Ottawa Civic Hospital, Ottawa, Canada.

Colony types $\mathrm{T} 1, \mathrm{~T} 2, \mathrm{~T} 3$, and $\mathrm{T} 4$ were isolated and maintained by daily passage on GC agar medium (BBL) containing 0.001 per cent. $\mathrm{Fe}\left(\mathrm{NO}_{3}\right)_{3}$ final concentration, 2 per cent defined supplement, and 1.5 per cent. Oxoid Agar as recommended by Kellogg and others (1963).

\section{(B) Challenge}

Cultures of $N$. gonorrhoeae grown on GC agar plates for $16 \mathrm{hrs}$ were suspended in Dulbecco phosphate buffer pH $7 \cdot 2$. The inoculum was adjusted to an optical density of 0.5 using a Bausch and Lomb Spectronic 20 at $540 \mathrm{~nm}$. (equivalent to $10^{9}$ colony-forming units per $\mathrm{ml}$.). Mice were anesthetized and injected intracerebrally with 0.03 $\mathrm{ml}$. of bacterial suspension at different challenge dilutions. $\mathrm{LD}_{50}$ values were calculated according to Reed and Muench (1938).

\section{(C) Vaccines}

$N$. gonorrhoeae strain 188, T1 and T4, were grown on GC agar for $16 \mathrm{hrs}$ and harvested in Sorensen's buffered saline $\mathrm{pH} 7 \cdot 2$. Vaccines were prepared by addition of formalin (final concentration 3 per cent.) to the above suspensions and incubation of the mixtures at room temperature for $30 \mathrm{~min}$. Cells were then sedimented $(2,800 \mathrm{G}$ for $20 \mathrm{~min}$.) and re-suspended in Sorensen's buffered saline containing 0.3 per cent. formalin. Vaccines were adjusted to an optical density of 0.5 using a Bausch and Lomb Spectronic 20 at $540 \mathrm{~nm}$. Mice were vaccinated intraperitoneally with a $0.5 \mathrm{ml}$. dose of vaccine and were challenged intracerebrally 2 weeks later with a dose equivalent to $10 \mathrm{LD}_{50} \mathrm{~s}$.

\section{(D) Purified lipopolysaccharide (LPS)}

LPS was prepared from $N$. gonorrhoeae T1 strain G9, as described in a recent report (Perry, Daoust, Diena, Ashton, and Wallace, 1974).

\section{Results and discussion}

Preliminary experiments indicated that of the several C57 mouse strains tested, the HPB black strain $\dagger$ was consistently the most susceptible to gonococcal infection. Female mice (16-18 gm.) were used in these studies, since the males were uniformly more resistant to gonococci. 
Throughout these experiments, strain 188 was regularly shown to be the most pathogenic, while the Ottawa and Inuvik clinical strains were less virulent. Death occurred from 1 to 6 days after challenge. Representative data in Table I show the pathogenic effects of living and heat-killed N. gonorrhoeae strain 188 when injected intracerebrally into mice. It appears from these data that, at the $1: 5$ dose level, T1 gonococci are more pathogenic for mice than the other types in comparison with the heatkilled challenge $(P<0.01)$. Subsequent titrations yielded essentially similar results.

Living gonococci were recovered up to the fifth day from the brain of mice, after intracerebral infection with $N$. gonorrhoeae $\mathrm{T} 1$. Organisms recovered 5 days after infection yielded essentially pure culture of $\mathrm{T} 1$ colonies, whereas T3 were present in earlier recoveries. Similarly, T1 colonies were obtained up to the fifth day from liver, kidney, and spleen (Table II).

TABLE II Recovery of N. gonorrhoeae from organs of HPB mice infected with $\mathrm{N}$. gonorrhoeae $T_{1}, T_{2}, T_{3}$, or $T_{4}$

\begin{tabular}{lll}
\hline & \multicolumn{2}{c}{ Colony type N. gonorrhoeae } \\
\cline { 3 - 3 } Organ & & $T_{2}, T_{3}, T_{4}$ \\
\hline Brain & + & + \\
Liver & + & - \\
Kidney & + & - \\
Spleen & + & - \\
\hline
\end{tabular}

Recovery of bacteria from brain and other organs having experimental infection with types T2, T3, and $\mathrm{T} 4$ was positive from brain tissue only, showing the inability of colony types other than $\mathrm{T} 1$ to cause a generalized infection. It is also of interest that, while the colony type of the bacteria recovered was consistent with the type of gonococci used in the challenge, $\mathrm{T} 1$ and $\mathrm{T} 2$ were occasionally recovered from T4 challenges, showing the possibility of type reversion in vivo.

Electron microscopy studies of experimentallyinfected mouse brain, sampled 4 days after intracerebral challenge with $\mathrm{T} 1$ gonococci will be fully described elsewhere (Ota, Diena, and Ashton, in preparation). Briefly, scattered intracellular bacteria were noted regularly. These seemed to be morphologically intact with complete cell walls, cytoplasmic membranes, and other intracytoplasmic structures. The microscopical examination also suggested that the infection by the gonococci was not localized but rather diffuse in the brain.

These data suggest that $N$. gonorrhoeae cells multiply in vivo after challenge of HPB black mice and succeed in producing an infection which may become generalized. Mice die from the combined effect of the bacterial mutiplication and the toxic effect of the released endotoxin.

Results to be published elsewhere (Diena, Ashton, and Wallace, unpublished observations) indicate that a strain of $\mathrm{C} 57$ mice deficient in the complement factor $C^{\prime} 5^{\star}$ is resistant to this $N$. gonorrhoeae challenge. On the other hand, the same strain of C57 mice, but with full expression of the complement $\dagger$, is susceptible to gonococcal infection suggesting the role of $\mathrm{C}^{\prime} 5$ released anaphylatoxin in producing a local damage (Gewurz, 1971) enabling the growth and multiplication of the bacteria.

This challenge was used to evaluate the potency of experimental gonococcal vaccines. Groups of mice were vaccinated with formalin-killed vaccines as

$\star_{\mathrm{B} 10}$ old (Jackson Laboratories, Bar Harbor, Maine).

†10 new (Jackson Laboratories, Bar Harbor, Maine).

TABLE I Representative data of pathogenicity of colony types of $\mathrm{N}$. gonorrhoeae, strain $\mathrm{I} 88$, in HPB black mouse

\begin{tabular}{|c|c|c|c|c|}
\hline Colony type & Bacterial dilution & $\begin{array}{l}\text { Challenge by live organisms } \\
\left(\frac{\text { No. of mice surviving }}{\text { No. of mice injected }}\right)\end{array}$ & $\begin{array}{l}\text { LD50 } \\
\text { (in colony-forming } \\
\text { units per dose) }\end{array}$ & $\begin{array}{l}\text { Challenge by heat-killed organisms } s^{\mathbf{a}} \\
\left(\frac{\text { No. of mice surviving }}{\text { No. of mice injected }}\right)\end{array}$ \\
\hline $\mathrm{T} 2$ & $\begin{array}{l}1: 1^{\mathrm{b}} \\
1: 5 \\
1: 25 \\
\end{array}$ & $\begin{array}{r}1 / 15(P<0.05) \\
11 / 15 \\
14 / 15\end{array}$ & $3.0-6 \cdot 0 \times 10^{6}$ & $\begin{array}{r}7 / 15 \\
13 / 15 \\
14 / 14\end{array}$ \\
\hline T3 & $\begin{array}{l}1: 1^{\mathrm{b}} \\
1: 5 \\
1: 25 \\
\end{array}$ & $\begin{array}{r}0 / 15(P<0.01) \\
7 / 15 \\
14 / 15 \\
\end{array}$ & $1.5-3.0 \times 10^{6}$ & $\begin{array}{r}7 / 15 \\
10 / 15 \\
15 / 15\end{array}$ \\
\hline $\mathrm{T} 4$ & $\begin{array}{l}1: 1^{b} \\
1: 5 \\
1: 25\end{array}$ & $\begin{array}{l}1 / 15(P<0 \cdot 01) \\
8 / 15 \\
14 / 15\end{array}$ & $2 \cdot 0-4 \cdot 0 \times 10^{6}$ & $\begin{array}{r}8 / 15 \\
11 / 15 \\
15 / 15\end{array}$ \\
\hline
\end{tabular}

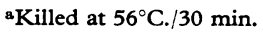

bViable count per dose of approximately $10-20 \times 10^{6}$ colony-forming units of gonococci

eSignificantly more virulent than the heat-killed challenge in the same horizontal line 
well as with purified smooth LPS from $N$. gonorrhoeae. Table III shows that good protection was achieved with gonococcal vaccines and with LPS at a concentration of $40 \mu \mathrm{g}$. per dose. The mouse intracerebral challenge is at present being evaluated with whole cell and purified homologous and heterologous vaccines.

TABLE III Mouse protection tests using gonococcal vaccines and purified lipopolysaccharide (LPS)

\begin{tabular}{|c|c|c|c|}
\hline \multirow[b]{2}{*}{ Vaccine } & \multicolumn{3}{|c|}{$\begin{array}{l}\text { Challenged with } 10 \text { LDso's of } \\
\text { strain No. } 188\end{array}$} \\
\hline & Test 1 & Test 2 & Test 3 \\
\hline Control, no vaccine & $1 / 15^{\mathrm{a}}$ & $0 / 15$ & $1 / 15$ \\
\hline N. gonorrhoeae $T_{1}$ & $10 / 15$ & $10 / 15^{b}$ & $13 / 15^{\prime}$ \\
\hline$T_{4}$ & $7 / 15$ & $3 / 15$ & $8 / 15$ \\
\hline $\begin{array}{r}\text { LPS ( } \mu \text { g.) } 40.0 \\
10.0 \\
2.5\end{array}$ & $\begin{array}{l}\text { N.T. } \\
\text { N.T. } \\
\text { N.T. }\end{array}$ & $\begin{array}{l}\text { N.T. } \\
\text { N.T. } \\
\text { N.T. }\end{array}$ & $\begin{array}{l}9 / 11 \\
6 / 15 \\
1 / 15\end{array}$ \\
\hline
\end{tabular}

a Survivors/injected

b Significantly better $(P<0.05)$ than the $T_{4}$ vaccine in the same column

\section{Summary}

An intracerebral challenge of HPB black mice with Neisseria gonorrhoeae is described. In this model, the mice died from 1 to 6 days after challenge, and T1 organisms were obtained up to the fifth day from brain, liver, kidney, and spleen. Experimental gonococcal vaccines gave good protection against the challenge.

Thanks are due to Mr. C. Perusse for providing us with the HPB black mouse strain used in these experiments.

\section{References}

ARKo, R. J. (1972) Science, 177, 1200

BUMgarNER, L. R., and FinkelsteIn, R. A. (1973) Infect. and Immun., 8, 919

BRowN, W. J., LUCAS, C. T., and KuHN, U. S. G. (1972)

Brit. F. vener. Dis., 48, 177

BuChaNAN, T. M., and Gotschlich, E. C. (1973) f. exp. Med., 137, 196

FlynN, J., and Waitkins, S. A. (1973) Brit. f. vener. Dis., 49, 432

GewURZ, H. (1971). In 'Immunobiology', ed. R. A. Good and D. W. Fisher, pp. 95-104. Sinauer Associates, Stanford, Conn.

GreenberG, L., Diena, B. B., Ashton, F. E., Wallace, R., KenNy, C. P., ZnAmirowski, R., Ferrari, H., and Atkinson, J. (1974) Canad. F. publ. Hlth, 65, 29

KellogG, D. S. Jr., Peacock, W. L., Deacon, W. E., Brown, L., and PIRKLE, C. I. (1963) f. Bact., 85, 1274

Perry, M. B., Daoust, V., Diena, B. B., Ashton, F. E., and Wallace, R. (1974) Canad. F. publ. Hlth, 65, 58

ReEd, L. J., and Muench, H. (1938) Amer. f. Hyg., 27, 493

Une infection intracérébrale par Neisseria gonorrhoeae chez la souris

SOMMAIRE

On décrit une infection intracérébrale par Neisseria gonorrhoeae chez des souris noires HPB. Avec ce modèle, les souris moururent de 1 à 6 jours après l'épreuve, et des organismes $\mathrm{T} 1$ furent obtenus jusqu'au sixième jour dans le cerveau, le foie, le rein et la rate. Les vaccins gonococciques expérimentés donnirent une bonne protection contre l'infection. 